\title{
THE IMPACT OF REPETITIVE XENOPHOBIC ATTACKS ON FUTURE FOREIGN DIRECT INVESTMENT: A CASE OF SOUTH AFRICA
}

\author{
Wellington Garikai Bonga \\ Department of Banking \& Finance, Great Zimbabwe University, Zimbabwe.
}

Article DOI: $\underline{\text { https://doi.org/10.36713/epra7943 }}$

DOI No: 10.36713/epra7943

\begin{abstract}
The debate of the link between xenophobia and importance of foreign direct investment is of interest. A phrase says it all, "One cannot want foreign money and hate foreign businesses at the same time." Does South Africa, as a country, love foreign investment, and by extension, foreign investors? A 'yes' and a 'no' answer will do for this question. Foreign direct investments are the most desirable form of capital inflows to emerging and developing countries. Many benefits are linked to accrue to a nation because of FDI inflows. FDI is climatic sensitive, and usually goes where it is wanted most and where conducive environment prevails. The South African nation is dominated by unending violence that also targets foreigners including their businesses. Effective policies to curb xenophobia seems to be lacking. There exist xenophobia denialism among the political leaders, making it more difficult to halt the problem. Letting the nation continue turning into a hostile destination for foreigners may pose a great investment challenge in the longer term. The path that South Africa is walking today, of protecting and failing to address issues of xenophobia, have a long term impact to investment in the country. Conflicts and violence attacks, hence xenophobia, continue to affect FDI flows several years into the future. The trend of net FDI has already shown a downward trend that may be attributed to issues of unrest persistent in the economy. The study strongly indicate that repetitive xenophobic attacks significantly impact future FDI inflows negatively. Immediate action is required to minimize the damage caused by xenophobia in the country. Investment climate restoration is required to ensure favorable economic growth path for the country.
\end{abstract}

KEYWORDS: Economic Growth, Foreigners, Foreign Direct Investment, Instability, Investment, Investment Climate, Socio-economic Development, Violence, Xenophobia, South Africa

JEL Codes: E22, F15, F18, F21, F22, F23, F51, F52, J71, J83, N40, N47, O19, P37.

\section{INTRODUCTION}

It is the objective of every nation to grow both economically and socially. Attaining a positive growth require a lot of effort through policy formulation, implementation and commitment. Various policy tools are used for favourable growth attainment. Attracting investment has for long been a one of the favourable strategies implemented by various nations to ensure growth and stability. A historical link between foreign direct investment (FDI) and economic development in Europe, America and Asia is on record. The same is yet to be significantly noticed for African nations. Africa is one region on the global map with countries still struggling to attract meaningful FDI and hence economic growth rates, which are often low (Bonga and Mahuni, 2018). As African nations lag behind developed nations in the development path, it is wise to adopt some of the strategies already known to have positive results. The concept has brought favorable results to now world giants in development. The Asian Tigers delivered their economic success story especially through FDI which occurred through inflow and outflow of same (Umezurike, Iwu and Asuelime; 2016). 


\section{International Journal of Southern Economic Light (JSEL)}

FDI is an international capital flow where foreign investors from one country invest their capital in another country (Wijaya et. al, 2020). Direct investment reflects the intention of attaining a lasting interest by a foreigner in an enterprise that is resident in another country. Usually, FDI is related to investment by foreign investors in productive assets. The "lasting interest" implies the existence of a long-term relationship between the direct investor and the direct investment enterprise and a significant degree of influence on the management of the latter (Duce and De España, 2003). FDI has been the largest single source of external finance for developing countries for many years. FDI is an integral part of an open and effective international economic system and a major catalyst to development (OECD, 2002). Muzurura (2016) indicated that the role played by FDI as a source of capital which augments domestic savings is attracting close attention in all developing countries. It has been recognized that the maximizing benefits of FDI for the host country can be significant, including technology spillovers, human capital formation support, enhancement of competitive business environment, contribution to international trade integration and improvement of enterprise development (Kurtishi-Kastrati, 2013).

South Africa (SA) is considered as a major economic hub of Africa. SA has the most developed, diversified and self-driven economy, with the gross domestic product (GDP) that is more than double of the other Southern African countries combined (Nkomo, 2006). However, reports suggest that the nation is struggling to tame the high levels of poverty and inequality. It is essential to have an accelerated pace of economic growth, lower unemployment, higher quality of life, lower demographic migration and lower poverty rates, thus attracting FDI has a direct and very important role to play (Lubeniqi, 2020). South Africa, as a country, needs large funds to carry out national development, and one potential source of financing is FDI. For many developing nations, FDI inflows remain crucial for economic development (Mahuni and Bonga, 2017). FDI can help the improvement of environment and social condition in the host country by relocating 'cleaner' technology and guiding to more socially responsible corporate policies (Kurtishi-Kastrati, 2013). As indicated by Busse and Hefeker (2005), the importance of changes in political institutions and of other relevant policies in host countries have received relatively little attention. Thorough examination is greatly emphasized on the effect of related issues like government stability, socio-economic conditions, investment profile, internal and external conflict, corruption, military in politics, religious tensions, law and order, ethnic tensions, democratic accountability, and the quality of bureaucracy on future FDI inflows into the country. National policies and the international investment architecture matter for attracting FDI to a larger number of developing countries and for reaping the full benefits of FDI for development (OECD, 2002).

Countries, just like individuals employ diversification strategies when investing. This is done by expanding business to other nations where there are strong ties or where they are permitted. In 2004, barely 10 years after apartheid in the country, SA companies invested in more than 600 projects in sub-Saharan Africa (Labor Research Service, 2010/2011). This was a very impressive investment decision for the country.

Some projects may be too big for a developing nation to venture into, either capital required is huge for the nation or technology required is too complex. Such businesses to kick start in a nation, there is greater need to invite foreign investors. Multinational companies (MNCs) are well known for partaking such investments because of their size and financial strength. As far as capital is concern, MNCs invest in long-term projects, taking risks and repatriating profits only when the projects yield returns (Kurtishi-Kastrati, 2013). Hill (2000) indicated that large MNCs may find it easier to borrow money from capital markets than host-country firms would.

\section{FOREIGN DIRECT INVESTMENT LEVELS IN SOUTH AFRICA}

South Africa has been a very attractive place for attracting FDI as it offers easy access by road, rail, air and sea ports. However, such a benefit is slowly fading being replaced by bad image caused by persistence of conflicts sometimes exploding to be serious violence and xenophobic attacks on foreigners and their businesses. Figure 1 below shows the level of net FDI inflows for South Africa. FDI is the sum of equity capital, reinvestment of earnings, other long-term capital, and short-term capital as shown in the balance of payments. The figures used are for total net, that is, net FDI in the reporting economy from foreign sources less net FDI by the reporting economy to the rest of the world. Data are in current U.S. dollars. 


\section{International Journal of Southern Economic Light (JSEL)}

- Peer Review Journal

Figure 1: Net FDI for South Africa (2009-2020) (US\$)

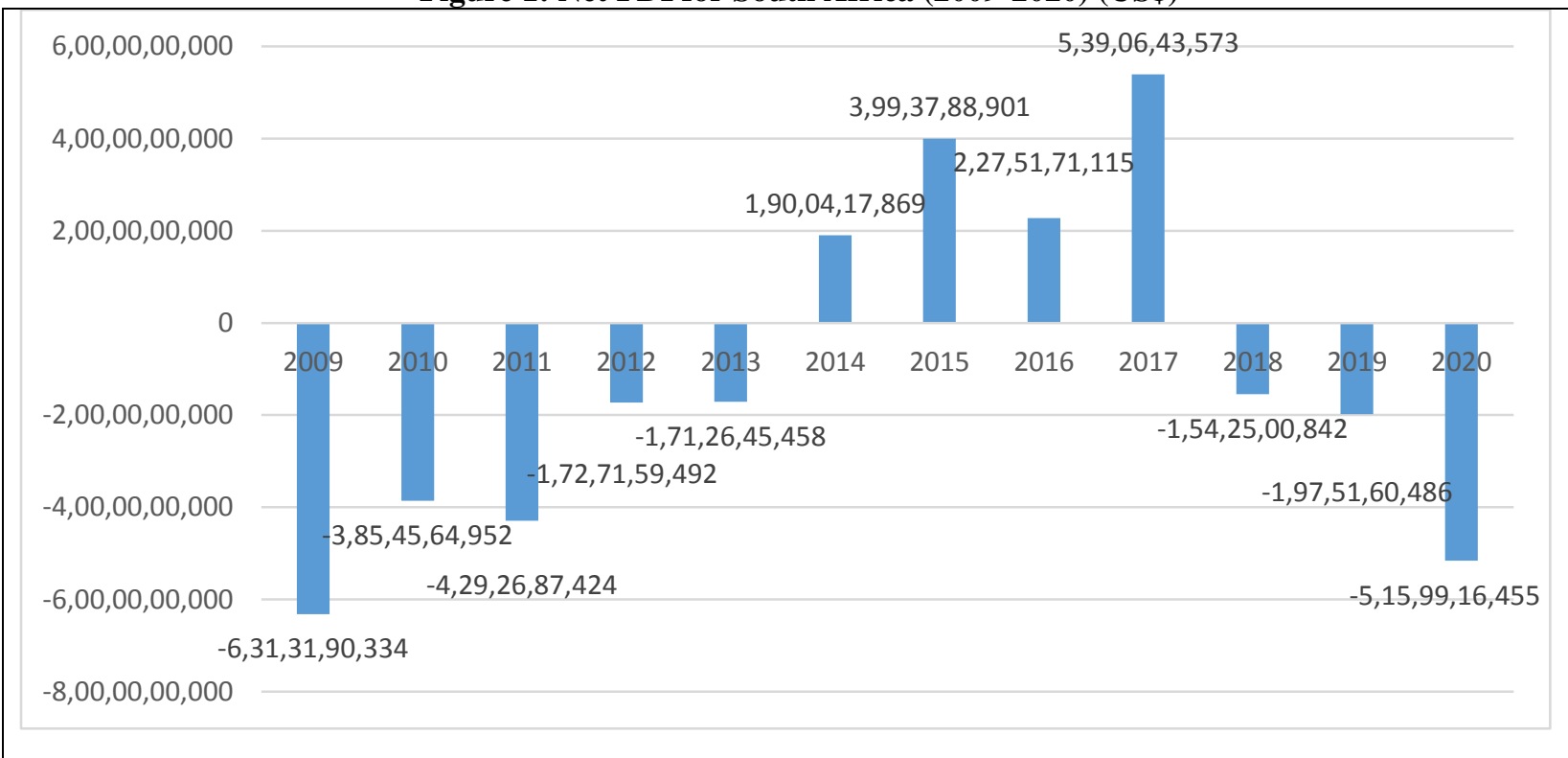

Source: https://knoema.com/atlas/South-Africa/topics/Economy/Balance-of-Payments-Capital-and-financialaccount/Net-FDI

Figure 1 above shows net FDI for the country for the period 2009-2020. The country registered negative net FDI for years 2009-2013, positives for years 2014-2017, and negative again for years 2018-2020. The trend was favourable when it moved from high negatives of 2009 declining through to 2013, and later positives recorded until 2017. Unfavorable results have been observed from 2018-2020, where the negatives continued to rise. Observing the trend shown by Figure 1, indicates instability in the way FDI is realized in the economy.

Many studies that explored the determinants of FDI dwelled much on macroeconomic variables, like economic growth, inflation, exchange rate among others. Hence, many recommendations for policies were biased towards such schools of thoughts. There is greater need to explore the other variables that defines investment climate especially from foreigners' perspective. Near studies found that there is a negative link between institutional uncertainty and private investment (Brunetti and Weder, 1998) and a positive relationship between FDI and intellectual property protection (Lee and Mansfield, 1996). Macroeconomic certainty and protection of property are key in foreign investment. Bonga (2019) indicated that there also exist spillover of uncertainty across economies. Supported by Christou et. al, (2019), if domestic uncertainty does increase, then international uncertainty feedbacks are likely to prolong the adverse effects on the domestic economy. Issues of repetitive xenophobia attacks in the country needs to be explored paying particular attention the impact it may impose on future FDI in the country. The negative values of net FDI may be contributed by the effects of repetitive xenophobia attacks thereby chasing away investors.

\section{IMPACT OF XENOPHOBIA ATTACKS IN SOUTH AFRICA}

The absorption of FDI flows has provided substantial growth impetus to developing and emerging market economies (Nakunyada, 2011). FDI net benefits do not accrue automatically, and also their importance varies according to host nation and conditions. Kurtishi-Kastrati (2013) stated that factors that hold back the full benefits of FDI in some developing countries include the level of general education and health, the technological level of hostcountry enterprises, insufficient openness to trade, weak competition and inadequate regulatory frameworks. Further to that violence and unrest in a nation may impact flow of FDI. After widespread violence in 2008 and 2015, South Africa is now clearly one of most hostile destinations in the world for African migrants (Claassen, 2017). To add, 
Mothibi, Roelofse and Tshivhase (2015) narrated that xenophobic attacks in South Africa in 2008 and 2015 sent shockwaves through the country and the world; around 70 people were killed while thousands were displaced; and, property and products of street vendors and shop owners were destroyed. Violent xenophobia has become a regular feature of South African life, where everyday animosity frequently spills over into violence against individual migrants and refugees and their economic enterprises (Crush and Ramachandran, 2014). There have been many reports highlighting the xenophobic attitude within South African communities as well as documented incidents of public and institutional violence and hostility towards foreigners (Marumo, Chakale and Mothelesi; 2019). Bond (2020) indicated that xenophobic upsurges regularly witnessed in Johannesburg suggest that this ongoing melting pot of African entrepreneurs suffers some of the continent's most extreme political-economic contradictions.

Repetitive xenophobic attacks clearly shows unrest and instability in a nation. In support Masikane, Hewitt and Toendepi (2020) indicated that the growing presence of anti-foreigner sentiments amongst South Africans, mostly those living in the metropolitan areas, is proving to be a major challenge. Between 2010 and 2015, sporadic xenophobic violence targeted towards black immigrants have persisted (Marumo, Chakale and Mothelesi; 2019). However, Tewolde (2020) rejects the Afro-phobia thesis and argues that other non-African migrants such as Asians (Pakistanis, Indians, Bangladeshis and Chinese) are also on the receiving end of xenophobia in post-apartheid South Africa. Such unending acts of violence creates bad destination venue for foreign investors, and worsens uncertainty for potential future foreign investors. Xenophobia in South Africa targets those who are in close proximity to disadvantaged Black South Africans and who are deemed outsiders (e.g., Asian, African even White residents and traders) (Tewolde, 2020). The economic development of emerging markets and developing countries depends to a large extent on the possibility to make profitable investments and accumulate capital (Busse and Hefeker, 2005). Projecting profits in such an unstable environment becomes difficult thereby causing potential investors to divert their attention to other competing climates. Kirchner (2008) argues that mistrust of FDI, or 'capital xenophobia', lowers a nation's chances of attracting the productive capital that contributes to rising living standards.

Impact of xenophobia is worse when there is retaliation from other states whose people would have been affected during attacks. It shakes the relationship between nations. Mahuni, Taru and Bonga (2020) narrated that xenophobia attacks in South Africa has impacted on relations of South Africa and other nations. It has affected the relationship between Nigeria and South Africa. Nigeria and South Africa are two leading countries in Africa, one in West Africa and the other in Southern Africa. Violent anti-immigrant demonstrations occurred in 2019 and Nigerian citizens' properties in Johannesburg were destroyed. As reported by Onke (2019), those who participated in the riot destroyed a number of target businesses owned by foreigners, particularly Nigerians. Some Nigerians were rescued back home, as some were burnt and seriously injured. In retaliation, angry Nigerians called for a boycott of South African companies operating in Nigeria, such as Shoprite, and Mobile Telephone Network (Sapphire, Jide and Oluwatimilehin; 2020). The repetitive occurrence of xenophobia attacks or conflicts means serious danger to the much wanted cooperation between the two nations. It impacts investment growth and integration agenda.

\section{REPETITIVE XENOPHOBIC ATTACKS AND INVESTMENT CLIMATE}

A good investment climate provides opportunities and incentives for firms-from microenterprises to multinationals - to invest productively, create jobs, and expand (World Development Report, 2005). In view of the potential role of FDI in accelerating growth and economic transformation, the creation of conducive investment climates has thus, assumed a central role in efforts geared at promoting FDI (Nakunyada, 2011). FDI inflow is significantly depressed by lack of social and economic freedom. Dadush and Braga (2005) noted that investment climate is particularly important to attract market seeking FDI and is also crucial for the association between FDI and domestic investment. Unstable political and economic environments deter FDI in the country. Repetitive xenophobia attacks in the country South Africa have changed the environment to be less conducive for foreign investment. The climate is not that attractive in the eyes of the investors (Bonga, 2019). Investors require as much certainty as possible about the direction of the economy (Nakunyada, 2011). With repetitive cases of violence, protests and xenophobic attacks, the country South Africa distort the growth compass used by investors to make viable decisions on investments. Improving the investment climate therefore offers an excellent opportunity for countries seeking to attract foreign direct investment (Hornberger, Battat and Kusek; 2011). Success in attracting 


\section{International Journal of Southern Economic Light (JSEL)}

non-primary sector FDI does require conflict abatement (Li, Musherd and Tanna, 2017). Civil conflict in particular has been shown to dramatically reduce growth by discouraging investment, and by causing the flight of financial, physical and human capital to safer havens (Collier, 1999; Fielding, 2004).

\section{CONCLUSION}

Given the appropriate host-country policies and a basic level of development, a preponderance of studies shows that FDI triggers technology spillovers, assists human capital formation, contributes to international trade integration, helps create a more competitive business environment and enhances enterprise development (OECD, 2002). Many studies have proved that FDI inflows are critical to the development of many economies, and South Africa is never an exception. Through increased and certain flows of FDI countries are able to ensure operations of some hard to approach sectors and the betterment through technologies of some existing sectors. FDI inflows brings with it many benefits to the economy. It can also be emphasized that FDI is brought in by foreigners, and hence there is migration into the country of those from foreign land. Foreigners when they are within a country have similar rights as natives and they have the right to be protected. To attract more long lasting investments in the country, a conducive environment should prevail, making the country more attractive.

The country South Africa, has witnessed some social challenges in the form of repetitive xenophobic attacks, violence and regular protests hence social unrest persist. The attacks have been targeting foreigners and their businesses, making the economy less attractive and unconducive for partaking business in the country. The repetitive activities have seen some foreigners pulling out of the country, and some were even rescued to return back as violence intensify causing deaths, serious injuries and displacement. Such activities do affect relations of the country with other countries, thereby impacting business flow. While some policies and strategies have been effected to address issues of xenophobia, they seem to be less working than expected. The country remains a hostile destination for foreign investment.

More has to be done, especially by political authorities to end issues of xenophobia. The root causes should be addressed. The investment climate should be restored in the country before further damage is done through the continued issues of violence on foreigners. A decline in FDI may have long lasting effects to the economy. For future flows of FDI to be secured, the right time to address issues of xenophobia is now. Investors bank on certainty of events, and peace within a nation. Investors compare environments before embarking on investment. Every time there is outbreak of violence, investors incur losses. Losses are never objectives of any business, hence, a strategy to avoid loss may be to pull out in a risky environment for a peaceful avenue.

In conclusion, there is a strong link between repetitive xenophobic attacks and declining future FDI inflows in a country. The damage imposed by xenophobia to investment flows will cause a nation to derail development and going for years trying to repair the damage. Early resolution is of critical importance.

\section{REFERENCES}

1. Bond, P. (2020). 'The State of the Continent is Good': African 'Foreigners' and Foreign Direct Investment, Seen from Subimperial South Africa. Africa Development / Afrique Et Développement, 45(2), 59-88.

2. Bonga, W.G and Mahuni, K. (2018). Assessing the Impact of Ease of Doing Business and Corruption on Economic Growth for Africa Free Trade Zone (AFTZ) Member States. Munich Personal RePEc Archive (MPRA) Paper No. 88932.

3. Bonga, W.G. (2019). Measuring Macroeconomic Uncertainty in Zimbabwe. Munich Personal RePEc Archive (MPRA) Paper No. 94759.

4. Brunetti, Aymo and Beatrice Weder (1998), Investment and Institutional Uncertainty: A Comparative Study of Different Uncertainty Measures, Weltwirtschaftliches Archiv, Vol. 134, No. 3, pp. 513-533.

5. Busse, M and Hefeker, C. (2005). Political Risk, Institutions and Foreign Direct Investment. HWWA Discussion Paper 315.

6. Christou, C., Gozgor, G., Gupta, R., and Lau, C-K. M. (2019). Are Uncertainties across the World Convergent?. University of Pretoria, Department of Economics, Working Paper Series, Working Paper: 2019-07.

7. Claassen, C. (2017). Explaining South African Xenophobia. Afrobarometer, Working Paper No. 173.

8. Collier, P. (1999). On the economic consequences of civil war. Oxford Economic Papers, Vol. 51, No. 1. 
9. Crush, J and Ramachandran, S. (2014). Xenophobic Violence in South Africa: Denialism, Minimalism, Realism. Migration Policy Series No. 66, Southern African Migration Programme (SAMP), International Migration Research Centre (IMRC).

10. Dadush, U and Braga, C.A.P. (2005). A Better Investment Climate and Foreign Direct Investment. OECD Global Forum for International Investment, Rio de Janeiro, Brazil.

11. Duce, M and De España, B. (2003). Definitions of Foreign Direct Investment (FDI): A Methodological Note. BIS Meeting, CGFS Working, March 11.

12. Fielding, D. (2004). How Does Violent Conflict Affect Investment Location Decisions: Evidence from Israel During the Intifada. Journal of Peace Research, Vol. 41, No. 4.

13. Hill, C. (2000): International Business - Competing in the Global Marketplace. University of Washington: Irwin McGraw-Hill.

14. Hornberger, Kusi; Battat, Joseph; Kusek, Peter. 2011. Attractive FDI : How Much Does Investment Climate Matter?. Viewpoint: Public Policy for the Private Sector; Note No. 327. World Bank, Washington, DC. (C) World Bank. https://openknowledge.worldbank.org/handle/10986/11060 License: CC BY 3.0 IGO."

15. Kirchner, S. (2008). Capital xenophobia II: foreign direct investment in Australia, sovereign wealth funds, and the rise of state capitalism. Centre for Independent Studies.

16. Kurtishi-Kastrati, S. (2013). The Effects of Foreign Direct Investments for Host Country's Economy. European Journal of Interdisciplinary Studies, Vol. 5, Issue 1, pp. 26-38.

17. Labor Research Service. (2010/2011). South African MNCs in Africa - Trends in 2010 / 2011, report covering MNCs submitted by Global Unions.

18. Lee, Jeong-Yeon and Edwin Mansfield (1996), Intellectual Property Protection and U.S. Foreign Direct Investment, Review of Economics and Statistics, Vol. 78, No. 2, pp. 181-186.

19. Li, C., Musherd, S.M. and Tanna, S. (2017). The impact of civil war on foreign direct investment flows to developing countries. Journal of International Trade and Economic Development 26(4):1-20.

20. Lubeniqi, G. (2020). Advantages, Disadvantages and the Performance of Foreign Direct Investment in the Republic of Kosovo 2008-2019. Prizren Social Science Journal, Vol. 4, Issue 1, pp. 14-19.

21. Mahuni, K and Bonga, W.G. (2017). Nexus Between Doing Business Indicators and Foreign Direct Investment for Zimbabwe: A Time Series Analysis. Dynamic Research Journals' Journal of Economics and Finance, Volume 2, Issue 2, pp: 01-08.

22. Mahuni, K., Taru, J and Bonga, W.G. (2020). Africa's Incomplete Cycles of Development. In "Africa in the Global Space, Vol. 1", Peter Lang Publishing, Inc., New York.

23. Marumo, P.O., Chakale, M. and Mothelesi, A. (2019). Xenophobia Attack and Development: A Discourse in South Africa. African Renaissance, Special Issue, pp 185-198.

24. Masikane, C.M., Hewitt, M.L. and Toendepi, J. (2020). 'Dynamics informing xenophobia and leadership response in South Africa', Acta Commercii 20(1), a704. https://doi.org/10.4102/ac.v20i1.704.

25. Mothibi, K.A., Roelofse, C.J and Tshivhase, T. (2015). Xenophobic attacks on foreign shop owners and street vendors in Louis Trichardt Central Business District, Limpopo Province. Td The Journal for Transdisciplinary Research in Southern Africa, 11(4), Special edition, pp. 151-162.

26. Muzurura, J. (2016). Determinants of foreign direct investment (FDI) in Zimbabwe: What factors matter? Research in Business and Economics Journal, Vol. 11, No. 1, pp. 1-19.

27. Nakunyada, W. (2011). A Conducive Investment Climate Vital for Sustained Economic Growth in Zimbabwe. ZEPARU Working Paper Series (ZWPS 02/11).

28. Nkomo, J.C. (2006). The Impact of Higher Oil Prices on Southern African Countries, Journal of Energy in Southern Africa, 17(1), pp. 1-17.

29. OECD (2002). Foreign Direct Investment for Development: Maximising Benefits, Minimising Costs. Organisation for Economic Co-Operation and Development.

30. Onke, N. (2019). South Africa Police Make More Arrests as Riots Spread. Retrieved July 21, 2021 from https://www.reuters.com/article/us-safrica-violence/south-african-police-make-morearresrts-as-riots-spreadidUSKCN1VO1ZW

31. Sapphire, K.P., Jide, I and Oluwatimilehin, D-A. (2020). Xenophobia and Migrants' Irritants in Nigeria-South Africa Relations: A Discourse. International Journal of Innovative Social Sciences \& Humanities Research 8(4):48-60.

32. Tewolde, A.I. (2020). Reframing Xenophobia in South Africa as Colour-Blind: The Limits of the Afro Phobia Thesis. Migration Letters, 17(3), 433-444. https://doi.org/10.33182/ml.v17i3.789.

33. Umezurike, S.A., Iwu, C.G and Asuelime, L. (2016). Socio-economic implications of South Africa's foreign direct investment in Southern African development. Investment Management and Financial Innovations, 13(3-2), 362-370. 
Volume: 9, Issue: 1, July 2021| Impact Factor (SJIF 2021):7.622 | Journal DOI: 10.36713/epra2712

ISSN: $2277-\mathbf{5 6 9 2}$

\section{International Journal of Southern Economic Light (JSEL)}

- Peer Review Journal

34. Wijaya, A.G., Astuti, D., Tarigan, Z.J.H and Edyanto, N. (2020). Determinants of Foreign Direct Investment in Indonesia "Evidence from Co-Integration and Error Correction Modeling”. SHS Web of Conferences 76, 01002.

35. World Development Report. (2005). A Better Investment Climate for Everyone. World Bank. 